\title{
Analysis on ICT Skills Present in Teachers in Active in Nine Spanish Territories
}

\author{
Inmaculada Tello Díaz-Maroto ${ }^{1}$ and Antonia Cascales Martínez ${ }^{2}$ \\ ${ }^{1}$ Universidad Autónoma de Madrid, Spain \\ ${ }^{2}$ Universidad de Murcia, Spain \\ inmaculada.tello@uam.es, antonia.cascales@um.es
}

\begin{abstract}
At the present time, it exists a debate about neutrality of the resources, but far from this controversy, what is clear is that people who employ them, give them value and meaning in the context in which it is used. The use that teachers give them, are not exempt from neutrality, so we have to practice them in the proper use thereof. This reflection leads us to consider the initial teacher education and with it, the continuous learning, both of them necessary and essential so that their educational work can be of quality. As can be gleaned from the skills mentioned by several authors, in the application of ICT in education is necessary a technical training and a pedagogical training. We must accompany the accessibility of such resources with the educational use of them. We will be then really using an education that uses ICT in their methodology in teaching and learning. ICT opens a new way to access information and a great communicative bridge for contact and learning. But for the teachers being able to carry out this work properly, they must first know the procedure, so they should be one of the leading figures involved in the process of teaching and learning, therefore it can be updated in the knowledge that the ICT demands, a proper use to it. To check the level of ICT training of teachers in service, we have applied a questionnaire on several dimensions related to ICT in the classroom: knowledge of these resources, teaching methodology, resource selection, evaluation and training received. The study sample consists of 147 teachers from four regions and 9 Spanish provinces. The sample used has been a purposive sampling, selecting teachers who have attended a training course on the use of ICT. The results show several differences in the knowledge of the ICT in the Spanish territory and a high demand for specific training adapted to the reality of each center.
\end{abstract}

Keywords: ICT Skills, Teachers, support, social justice.

\section{Introduction}

If we understand education as the basis for the development of any society, we must also seek to develop the Social Justice in the classroom, in order to create an egalitarian society and work towards building the society we long . "The yearning for greater social justice arises, first, by the clear perception of the many and growing injustices that surround us , but also in search of a better society ". In this sense, "the question of 
the kind of society that we care and that we want to work, to the question above objectives, meaning or purpose of education" [1].

The accessibility and use of information technology and communication (ICT) open other gaps that may have effects on integration and social cohesion. That is why decisions about ICT are now related to issues that promote equity and social justice [2].That is why the current rules, states that one of the principles of education ensuring access for all to ICTs, fostering social justice. In this line, makes explicit reference to the responsible use of ICT as a pedagogical principle and as an educational goal, recognizing the need for centers with the necessary infrastructure to promote the use of information technologies and communication, as well as the necessary teacher training in this field.

We observe two important areas to be analyzed to improve the quality and equity in the classroom, the appropriate use of ICT and promoting Curricular Justice are evident. Therefore, the proper selection and use of ICT in the classroom is so necessary to promote more than a digital divide in schools, we achieve the opposite, strengthen and promote social justice in all classrooms.

Prado (2011) as Deputy Executive Secretary of ECLAC, considered the digital divide in the access and the use of ICT, emerging issues of inequality and welfare. However, for once the previous requirements of accessibility and connectivity technology, the basic processes of digital literacy training, and practical use of the tools of elementary information and communication technologies (ICT ) for the operation of the mass media ( mass media ), it is necessary to transcend the technical and technological approach that has been taken of ICT and mediational and interactional explore their role in the formation, which contribute to fair social conditions.

The potential of ICT for the educational process is proposed, which is required to reformulate education and empower " ... peer collaboration , active participation of students in their own learning process and increasing individualization processes through greater promotion of creativity and autonomy " [3] [4].This is achieved when the subjects constructed in relation to others, when the spaces for participation, etc. are provided., As expressed [5], ICT backbone, political, social , economic, cultural development.

\section{Design Process, Methods and Results}

After reviewing the literature and be aware of the need for teacher training in the various stages of education in the knowledge society, we have carried out the data collection of the knowledge about claiming to have teachers through the implementation of a questionnaire.

To train teachers in the appropriate use of ICT, we must first know the reality of training teachers in service. For this reason, we have applied a questionnaire to analyze the knowledge that teachers have to attend a training course on "Teacher Training in the use of ICT in the field of inclusive schools and grade schools." The questionnaire was administered to a sample of 147 teachers from various regions of the Spanish territory.

The sample was selected through an intentional non-probability sampling, it was applied to those teachers who attended a training course related to the appropriate use of ICT. Attendees of the course teachers, $100 \%$ of them responded. The questionnaire 
consists of 29 items , 7 questions related to the characteristics of the sample for subsequent contrasts, a second part in which printing is to know that teachers have about their level of knowledge with respect to ICT , the third part relating to the appraisal of teachers regarding the methodology they use ICT ; quarter related to the selection of appropriate resources, one-fifth to assess the use of ICT in the evaluation, and a final part to refer to teacher training in the appropriate use of ICT. The aim of the study was to perform an analysis of the degree of knowledge and perspectives that teachers in different regions of Spain have regarding the appropriate use of ICT in education. Based on the results, the goal is to offer training tailored to the needs of each locality.

The results indicate several differences respect to various aspects assessed (level of knowledge, methodology, resource selection, evaluation and training) in function of the locality from which teachers; we found statistically significant differences in all aspects except for the selection of ICT resources (no significant differences). There have done Scheffé tests to detect the groups among which those differences exist, for example, we detected differences in some cases in the evaluation of the chosen methodology, highlighting Cáceres above Sevilla and Granada. (Table 1)

Table 1. ANOVA results of a factor between different aspects and locality

\begin{tabular}{lcc}
\hline & F & Sig. \\
\hline Level of knowledge & 2,650 & 0,010 \\
Methodology & 4,974 & 0,000 \\
Selecting resources & 1,721 & 0,099 \\
Evaluation & 4,126 & 0,000 \\
Training & 3,547 & 0,001 \\
\hline
\end{tabular}

A variable that also could show us a interesting contrast was the age, in base the speech that sometimes is used about that older teachers are more reluctant to incorporating ICT in their classroom. But strikingly, they found no statistically significant relationships between the various aspects and age. Also, we haven't obtained relationships between the various aspects and years of teaching experience. However, it has been statistically significant relationships between the aspect concerning the methodology and terms of training with respect to the educational level at which he teaches teachers. Thus, it is observed in both respects a statistically significant and positive, which indicates that the higher the educational level of teachers, they value most the methodology used with ICT and the formation in values, which indicate greater use of ICT in the classroom at higher levels.

Finally we asked them the type of school in which they imparted their teaching, by also study if there are differences in different aspects evaluated, depending on the type of facility in which they exercise their professional work. As we have analyzed the characteristics of the sample, we have saw there is a higher proportion of teachers in public school in contrast to private schools or rural schools, to private schools or rural schools, yet we have proceeded to perform ANOVA to analyze the results. In this sense, we can see in Table 2 that there are no statistically significant differences in the assessment of aspects of the study, depending on the type of school in which teachers work. 
Table 2. Student t test results between different aspects and type of organization

\begin{tabular}{lcc}
\hline & $F$ & Sig. \\
\hline Level of knowledge & 0,668 & 0,514 \\
Methodology & 0,961 & 0,385 \\
Selecting resources & 0,170 & 0,844 \\
Evaluation & 1,747 & 0,178 \\
Training & 1,030 & 0,360 \\
\hline
\end{tabular}

\section{Conclusions}

Based on the results obtained and the bibliographic analysis regarding the issue at hand, it has been possible to note some observations that allow us to design a training plan to accomplish with future teachers, at least through the Master Teacher Training for Secondary Education. We can highlight among the main conclusions:

- Generally schools do not promote Education for Development, Social Justice and Active Citizenship.

- It seems that future teachers of secondary respondents are aware that those concepts are not identical, but have no clear differences between them.

- We have to promote this concept in all the educational levels using news methodologies.

\section{References}

1. Murillo, F.J., Hernández-Castilla, R.: Hacia un Concepto de Justicia Social. REICE. Revista Iberoamericana sobre Calidad, Eficacia y Cambio en Educación 9(4), 7-23 (2011)

2. Duro, E.: Programa Desafío. La inclusión de adolescentes a la escuela en municipios de la provincia de Buenos Aires. UNICEF, Mime (2007)

3. Pérez, A.I. (ed.): Reinventar la profesión docente. Nuevas perspectivas y escenarios en la era de la formación y de la incertidumbre (Tema monográfico). Revista Interuniversitaria de Formación del Profesorado, vol. 68(24, 2) (2010)

4. Pérez, A.: Escuela 2.0. Educación para el mundo digital (2010), [En Red] Disponible en, http: //www.injuve.es/sites/default/files/RJ92-06.pdf

5. Queraltó, R.: Ética y sociedad tecnológica: pirámide y retícula. Universidad de Sevilla, Sevilla (2002) [En Red] Disponible en, http://institucional.us.es/ revistas/argumentos/5/art_2.pdf 